\title{
Winter wheat grain yield and its components in the North China Plain: irrigation management, cultivation, and climate
}

\author{
Lihua Lv ${ }^{1}$, Yanrong Yao1, Lihua Zhang ${ }^{1}$, Zhiqiang Dong ${ }^{2}$, Xiuling Jia ${ }^{1 *}$, Shuangbo Liang ${ }^{*}$, \\ and Junjie $\mathbf{J i}^{2}$
}

\begin{abstract}
Irrigation has been identified as the main driving factor of groundwater drawdown in the North China Plain (NCP). In order to develop appropriate irrigation strategies for satisfactory yields of wheat (Triticum aestivum L.), grain yield (GY), yield components, and water use efficiency (WUE) were studied. A field experiment was conducted with two types of winter wheat, 'Shimai15' and 'Shixin733', and five irrigation treatments, including rainfed and four spring irrigation water applications, in four growing seasons (2005 to 2009). Results showed that maximum GY was achieved with three irrigation treatments in the 2005-2006 and 2008-2009 dry seasons and two irrigation treatments in the 2006-2007 normal season. However, in the 2007-2008 wet season, the four irrigation treatments, especially the additional irrigation event at the reviving stage (28), produced maximum GY. Grain yield was significantly related to seasonal full evapotranspiration (ET) and 410 to $530 \mathrm{~mm}$ of seasonal full ET, including $143 \mathrm{~mm}$ rainfall and $214 \mathrm{~mm}$ irrigation water, which led to maximum GY. The two types of cultivars responded differently to irrigation management in different rainfall years. The yield of the watersaving cv. 'Shimai 15' was much higher in the dry seasons than in the other seasons. Variations of yield components were mainly caused by irrigation time and meteorological factors. The higher accumulated temperature during the sowing and tillering stages (24) and irrigation or precipitation at the reviving stage (28) significantly improved tiller growth. The lower average temperature in March and April greatly increased grain number per spike. Sunshine duration played a decisive role in improving grain weight. Our results provide very useful information about irrigation time and frequency of winter wheat in the NCP in order to obtain high yield but reduce the use of underground water.
\end{abstract}

Key words: Evapotranspiration, grain yield, North China Plain, soil water depletion, Triticum aestivum.

\section{INTRODUCTION}

The North China Plain (NCP) is one of the most important agricultural regions and supplies more than $50 \%$ of China's wheat production. The region has a monsoon climate with less than $30 \%$ precipitation falling in winter (approximately $109 \mathrm{~mm}$ ), which is much lower than wheat requirements. Moreover, annual precipitation in the study area was observed to have decreased by $170 \mathrm{~mm}$ from the 1960s to 2005 (Sun et al., 2010). Irrigation using groundwater is therefore quite necessary to maintain the high agricultural production. Today, approximately $70 \%$ of extracted water resources for agriculture, of which approximately $70 \%$ is for wheat irrigation, are pumped

\footnotetext{
${ }^{1}$ Institute of Cereal and Oil Crops, Hebei Academy of Agricultural and Forestry Sciences, 162 Hengshan Road, Shijiazhuang, Hebei, China. 050035 .

"Corresponding authors (jiax12005@aliyun.com; 12201@163.com). ${ }^{2}$ Ministry of Agriculture, Scientific Observing and Experimental Station of Crop Cultivation in North China, China.

Received: 21 March 2013

Accepted: 3 July 2013.

doi:10.4067/S0718-58392013000300005
}

from groundwater in Hebei Province of the NCP. The expansion of irrigation over the years has led to a rapidly falling groundwater table. The groundwater table in the Piedmont Plain has decreased approximately $1 \mathrm{~m} \mathrm{yr}^{-1}$ in the last $20 \mathrm{yr}$ (Jia and Liu, 2002). It is urgent and essential to develop an optimum policy to avoid further overexploitation of groundwater and maintain sustainable crop production.

Cultivation, irrigation practices, and climate are the most important factors that influence wheat growth and yield (Al-Kaisi et al., 1997; Ghahraman and Sepaskhah, 1997; Zhang et al., 2003). There is a need to develop drought-resistant cultivars with higher grain yield (GY) in water deficit conditions. The superior performance of cultivation under dryland conditions is attributed to the ability of cultivars to extract a significant proportion of water from deep soil layers (Angadi and Entz, 2002). The scarcity of roots in deep soil layers often restricts full utilization of available soil water (Barraclough and Weir, 1988).

Many studies have been carried out to search for the best ways to efficiently use irrigation water and improve crop yield (Shen and Yu, 1998; Zhang et al., 2010). Plant 
water use efficiency (WUE) depends on the quantities applied and timing. Deficit irrigation, defined as applying water below full crop-water requirements, is an important tool to achieve the goal of reducing irrigation water use (Fereres and Soriano, 2007). Improving irrigation efficiency by applying deficit irrigation is an important management practice, especially in regions with serious water shortage. A more frequently irrigated crop might increase soil evaporation, so that with a limited irrigation supply, balancing the irrigation amount per application and irrigation frequency with root water uptake would be expected to affect yield as well as WUE.

Despite ongoing improvements in technology and crop varieties, weather is still the main uncontrollable factor that affects agricultural production. Williams (1971-1972) found that within a large wheat growing region, large differences were found in the relationships between wheat yield fluctuations and weather variations, especially in the driest areas. The amount of annual precipitation and its seasonal distribution are crucial for agricultural production in the NCP (Sun et al., 2010). Some studies found that precipitation at sowing is important to increase yield. Low rainfall and low soil water content at sowing slow down the germination process, reduce the percentage of germination, and planting density (Passioura, 2006). However, if plants use too much water before flowering, subsequent water stress caused by lower rainfall levels leads to premature crop senescence, low yield, or often poor grain quality. This is because plants set a large number of seeds but cannot produce enough carbohydrates to fill them all (Angus and Van Herwaarden, 2001). It is therefore imperative to establish a rational irrigation schedule in accordance with annual precipitation, its seasonal distribution, and crop water requirements.

The rate of many crop plant growth and development processes is controlled by temperature. Soil moisture loss through evaporationincreased by 35 to $45 \mathrm{~mm}$ and WUE decreased by $7.3 \%$ from the 1950 s to the $1990 \mathrm{~s}$ because temperatures increased (Xiao and Gen, 1999). Supplemental irrigation is beneficial to increase crop yields. Extreme temperature fluctuations can affect the survival of crop plants or plant organs. Winter rye crop density and number of kernels of are positively influenced by warm weather in autumn at Berlin-Dahlem. An early start of the growing season after winter is also important for the satisfactory development of these components. Moderate temperatures prior to the beginning of shooting prolong the spikelet formation period and leads to an increased number of kernels per ear. High temperatures at the flowering stage can reduce the potential number of grains; it also reduces the duration of the milk grain period and kernel weight of winter rye (Chmielewski and Kohn, 2000). The current extreme temperature will be more frequent for the NCP. We consider how episodes of hot temperatures will affect winter wheat yield. It is very important to identify the atmospheric conditions that control the formation and reduction of yield components.

One of the major factors affecting GY in May is solar radiation. Grain yields have been found to be very sensitive to changes in radiation levels around anthesis (Mitchell et al., 1996). The date of anthesis determines the onset of the milk grain phase. To analyze the importance of the influence of climate on yield, Landau et al. (2000) applied a sub-model and found a positive effect of radiation around the early reproductive phase and anthesis because of increased photosynthesis. The model predicts that rainfall and radiation levels in the early reproductive phase interact with each other. Once a drought threshold is reached, radiation has a negative effect, which depends on the drought level.

The NCP is one of the places with extreme water shortage and climatic changes in China. Applying rational irrigation is an important management practice to relieve the pressure of water shortage and climate change. In the present study, we investigated the influence of irrigation management, meteorological variables, and specific genotype in winter wheat GY, yield components, and WUE. The main objectives of this study were to develop appropriate irrigation strategies to obtain satisfactory yields using the least amount of irrigated water and to look for optimal measures that adapt to different types of weather by assessing the impact of weather changes on yield.

\section{MATERIALS AND METHODS}

\section{Experimental site}

Winter wheat (Triticum aestivum L.) was grown in the Gaocheng Experimental Base of the Institute of Cereal and Oil Crops, Hebei Academy of Agricultural and Forestry Sciences from 2005 to 2009. The experimental site is located at the base of Taihang Mountain $\left(37^{\circ} 56^{\prime} \mathrm{N}\right.$, $\left.114^{\circ} 42^{\prime} \mathrm{E}\right)$, which is high-yield farmland in the NCP. The area is in a monsoon climatic zone with an average annual precipitation of approximately $484 \mathrm{~mm}$. However, rainfall in the winter wheat growing season is less than $30 \%$ of total rainfall. Irrigation is quite important for this winter crop. Its well-drained loamy soil with a deep profile is most suitable for crop growth. Soil organic matter for the 0 to $20 \mathrm{~cm}$ tillage soil layer is $15.5 \mathrm{~g} \mathrm{~kg}^{-1}$. Total $\mathrm{N}$ is 0.97 $\mathrm{g} \mathrm{kg}^{-1}$ and available $\mathrm{P}$ and $\mathrm{K}$ are 19.46 and $91.00 \mathrm{mg} \mathrm{kg}^{-1}$, respectively.

\section{Winter wheat cultivars}

The wheat cultivars under study were 'Shimai15' (SM15) and 'Shixin733' (SX733), which were commonly grown in the region. SM15 is widely recognized as a watersaving wheat (Guo et al., 2010), and it was produced by the Shijiazhuang Academy of Agricultural Science in 2002. SX733 is a high-yielding cultivar and was produced by the Institute of Shijiazhuang New Wheat Breeding Technology in 1998. Both are semi-winter cultivars with 
a 240 to 243 d growth period. SM15 differs from SX733 in that it has a stronger tillering ability.

\section{Trial arrangements}

Winter wheat was sown in early to middle October and harvested within the first $10 \mathrm{~d}$ of June with a plot combine seeder (2756285100100, Wintersteiger, 4910 Ried im Innkreis, Upper Austria, Austria). The sowing and harvest dates and seedling density are shown in Table 1. Chemical fertilizers were applied before cultivation at a base rate of $120 \mathrm{~kg} \mathrm{~N} \mathrm{ha}^{-1}$ (using urea plus diammonium phosphate [DAP]), $60 \mathrm{~kg} \mathrm{P}^{-1}$ (DAP), and $85 \mathrm{~kg} \mathrm{~K} \mathrm{ha}^{-1}(\mathrm{KCl})$. Nitrogen (urea) was top-dressed again during the first spring irrigation event in at the rate of $120 \mathrm{~kg} \mathrm{ha}^{-1}$. Plots were randomly chosen for the field experiments with four replicates of the five irrigation treatments (Table 2). They were separated by a $1.5 \mathrm{~m}$ wide zone planted with non-irrigated winter wheat to minimize mutual effects of adjacent plots. The size of each plot was $25.2 \mathrm{~m}^{2}$. Row spacing was $0.15 \mathrm{~m}$. The five irrigation treatments were rainfed (I0), and one (I1), two (I2), three (I3), and four (I4) irrigation events based on the crop development stage (Table 2). For each irrigation event, 60 to $70 \mathrm{~mm}$ water (90 to $100 \mathrm{~mm}$ in 2008-2009) was applied to the soil by surface irrigation with a low-pressure tube water transportation system and a flow meter to record the

Table 1. Seedling density, sowing, flowering, and harvest dates for both winter wheat cultivars in the four growing seasons between 2005 and 2009.

\begin{tabular}{lcccc}
\hline Season & Seedling density & Sowing date & Flowering date & Harvest date \\
\hline & plants $\mathrm{m}^{-2}$ & \multicolumn{3}{c}{ month/day } \\
$2005-2006$ & 300 & $10 / 6$ & $5 / 7$ & $6 / 10$ \\
$2006-2007$ & 300 & $10 / 10$ & $5 / 5$ & $6 / 8$ \\
$2007-2008$ & 375 & $10 / 18$ & $5 / 2-5 / 5$ & $6 / 8$ \\
$2008-2009$ & 375 & $10 / 14$ & $5 / 4$ & $6 / 9$ \\
\hline
\end{tabular}

Table 2. Irrigation time and amount of water from 2005 to 2009 . amount of irrigation applied to each plot. Irrigation times and amounts are shown in Table 2.

Rainfall during winter wheat growth from 2005 to 2009 is shown in Table 3. Compared with the long-term average, 2005-2006 and 2008-2009 were dry seasons, while 2006-2007 and 2007-2008 were a normal and wet season, respectively. Other meteorological parameters, such as air temperature, humidity, sunshine duration, and wind speed, were also collected by a weather station installed $200 \mathrm{~m}$ away from the experimental field where reference evapotranspiration was calculated.

\section{Measurements}

Grain yield and yield components. Wheat was harvested with a plot combine harvester (CLASSIC, Wintersteiger, 4910 Ried im Innkreis, Upper Austria, Austria). Grains were air-dried prior to recording weight. Grain water content was approximately $13 \%$. Spike number per unit area $\left(0.3 \mathrm{~m}^{2}\right)$ was counted before harvest and 40 winter wheat plants were collected from each plot to determine kernel number per spike (ear). Winter wheat 1000 -seed weight was measured.

Soil water balance. Soil water content was monitored at an interval of $10 \mathrm{~cm}$ to a depth of $2 \mathrm{~m}$ with a neutron soil moisture meter (CNC503B, Beijing Keyuan ChaoNeng Company, Beijing, China) with access tubes installed at the center of the plots. Total water use or ET was calculated by the soil water balance equation for the growing season as follows:

$$
\mathrm{ET}=\mathrm{P}+\mathrm{I}+\Delta \mathrm{W}-\mathrm{R}-\mathrm{D}+\mathrm{CR}
$$

where $E T$ is total water volume used during a given growing period, $P$ is precipitation, $I$ is irrigation, $\Delta W$ was obtained by soil water content at sowing minus soil water content at harvest in the $2 \mathrm{~m}$ root zone depth, $R$ is runoff,

\begin{tabular}{|c|c|c|c|c|c|c|c|c|c|c|}
\hline \multirow[b]{2}{*}{ Season } & \multirow[b]{2}{*}{$\begin{array}{l}\text { Treat- } \\
\text { ment }\end{array}$} & \multirow[b]{2}{*}{$\begin{array}{l}\text { Irrigation } \\
\text { frequency }\end{array}$} & \multirow[b]{2}{*}{ Irrigation time } & \multicolumn{6}{|c|}{ Irrigation in growth stage and amount (mm) } & \multirow{2}{*}{$\begin{array}{l}\text { Total } \\
\text { irrigation } \\
\text { amount } \\
(\mathrm{mm})\end{array}$} \\
\hline & & & & $\begin{array}{l}\text { Tillering } \\
\text { (24) }\end{array}$ & $\begin{array}{l}\text { Reviving } \\
\text { (28) }\end{array}$ & $\begin{array}{l}\text { Erecting } \\
\quad(30)\end{array}$ & $\begin{array}{l}\text { Jointing } \\
\text { (31) }\end{array}$ & $\begin{array}{l}\text { Anthesis } \\
(60)\end{array}$ & $\begin{array}{l}\text { Grain milk } \\
(75)\end{array}$ & \\
\hline \multirow[t]{5}{*}{$2005-2006$} & I0 & 1 & $30 \mathrm{Nov}$ & 51.4 & - & - & - & - & - & 51.4 \\
\hline & I1 & 2 & 30 Nov, 6 April & 51.4 & - & - & 71.4 & - & - & 122.8 \\
\hline & $\mathrm{I} 2$ & 3 & 30 Nov, 6 April, 2 May & 51.4 & - & - & 71.4 & 57.1 & - & 179.9 \\
\hline & I3 & 4 & 30 Nov, 6 April, 2 May, 23 May & 51.4 & - & - & 71.4 & 57.1 & 51.4 & 231.3 \\
\hline & I4 & 5 & 30 Nov, 20 March, 6 April, 2 May, 23, May & 57.1 & - & 65.7 & 57.1 & 57.1 & 51.4 & 288.4 \\
\hline \multirow[t]{5}{*}{$2006-2007$} & I0 & 0 & & - & - & - & - & - & - & \\
\hline & I1 & 1 & 8 April & - & - & - & 66.1 & - & - & 66.1 \\
\hline & $\mathrm{I} 2$ & 2 & 8 April, 3 May & - & - & - & 66.1 & 64.3 & - & 130.4 \\
\hline & $\mathrm{I} 3$ & 3 & 8 April, 3 May, 24 May & - & - & - & 66.1 & 64.3 & 52.5 & 182.9 \\
\hline & $\mathrm{I} 4$ & 4 & 14 March, 8 April, 3 May, 24 May & - & 71.4 & - & 66.1 & 64.3 & 52.5 & 254.3 \\
\hline \multirow[t]{5}{*}{ 2007-2008 } & I0 & 0 & & - & - & - & - & - & - & \\
\hline & I1 & 1 & 7 April & - & - & - & 56.6 & - & - & 56.6 \\
\hline & $\mathrm{I} 2$ & 2 & 26 March, 6 May & - & - & 77.9 & - & 67.6 & - & 145.5 \\
\hline & I3 & 3 & 26 March, 6 May, 24 May & - & - & 69.4 & - & 66.1 & 57.6 & 193.1 \\
\hline & $\mathrm{I} 4$ & 4 & 10 March, 7 April, 6 May, 24 May & - & 77.3 & - & 56.6 & 66.1 & 57.6 & 257.6 \\
\hline \multirow[t]{5}{*}{ 2008-2009 } & I0 & 0 & & - & - & - & - & - & - & \\
\hline & I1 & 1 & 8 April & - & - & - & 99.5 & - & - & 99.5 \\
\hline & $\mathrm{I} 2$ & 2 & 8 April, 4 May & - & - & - & 101.5 & 111.0 & - & 212.5 \\
\hline & $\mathrm{I} 3$ & 3 & 8 April, 4 May, 25 May & - & - & - & 101.5 & 111.0 & 101.6 & 314.1 \\
\hline & $\mathrm{I} 4$ & 4 & 13 March, 8 April, 4 May, 25 May & - & 104.2 & - & 88.3 & 83.4 & 97.5 & 373.4 \\
\hline
\end{tabular}


Table 3. Monthly precipitation at Gaocheng Station.

\begin{tabular}{|c|c|c|c|c|c|c|c|c|c|c|c|}
\hline \multirow[b]{2}{*}{ Season } & \multirow[b]{2}{*}{ Treatment } & \multicolumn{9}{|c|}{ Rainfall (mm) } & \multirow{2}{*}{$\begin{array}{l}\text { Total } \\
(\mathrm{mm})\end{array}$} \\
\hline & & Oct & Nov & Dec & Jan & Feb & March & April & May & June & \\
\hline \multirow[t]{3}{*}{ 2005-2006 } & $\mathrm{I} 0, \mathrm{I} 1, \mathrm{I} 2$ & 3.5 & 0.0 & 0.4 & 1.6 & 0.5 & 0.0 & 14.2 & 62.0 & 8.2 & 90.4 \\
\hline & $\mathrm{I} 3$ & 3.5 & 0.0 & 0.4 & 1.6 & 0.5 & 0.0 & 14.2 & 62.0 & 18.7 & 100.9 \\
\hline & I4 & 3.5 & 0.0 & 0.4 & 1.6 & 0.5 & 0.0 & 14.2 & 62.0 & 19.9 & 102.1 \\
\hline $2006-2007$ & $\mathrm{I} 0, \mathrm{I} 1, \mathrm{I} 2, \mathrm{I} 3, \mathrm{I} 4$ & 0.5 & 18.9 & 5.5 & 0.0 & 0.0 & 46.4 & 2.7 & 64.0 & 0.0 & 125.4 \\
\hline \multirow[t]{2}{*}{$2007-2008$} & $\mathrm{I} 0, \mathrm{I} 1$ & 1.6 & 0.3 & 2.4 & 0.9 & 0.0 & 18.5 & 46.1 & 58.8 & 34.1 & 162.7 \\
\hline & $\mathrm{I} 2, \mathrm{I} 3, \mathrm{I} 4$ & 1.6 & 0.3 & 2.4 & 0.9 & 0.0 & 18.5 & 46.1 & 58.8 & 85.4 & 214.0 \\
\hline 2008-2009 & $\mathrm{I} 0, \mathrm{I} 1, \mathrm{I} 2, \mathrm{I} 3, \mathrm{I} 4$ & 11.5 & 0.0 & 0.0 & 0.0 & 8.7 & 6.5 & 6.0 & 30.5 & 29.4 & 92.6 \\
\hline Average (19 & & 14.7 & 15.8 & 3.3 & 4.3 & 6.1 & 12.6 & 21.9 & 42.3 & 21.5 & 142.6 \\
\hline
\end{tabular}

October represents period from the sowing date to 31 Oct and June represents period from 1 June to harvest date. For the average of 1986 -2010, Oct represents the last $20 \mathrm{~d}$ of Oct and June represents the first $10 \mathrm{~d}$ of June. Winter wheat was generally harvested around 10 June.

I0: rainfed; I1: one irrigation event; I2: two irrigation events; I3: three irrigation events; I4: four irrigation events.

$D$ is root zone drainage, and $C R$ is capillary rise to the root zone. The groundwater table at the station was $28 \mathrm{~m}$ below soil surface and CR was negligible (Liu and Wei, 1989). Runoff was also ignored because it was scarce in the NCP. Drainage was obtained by multiplying a recharge coefficient $(\alpha)$ with the sum of water from irrigation $(I)$ and effective rainfall $(P): \mathrm{D}=\alpha(\mathrm{P}+\mathrm{I})$. In the present study, a different coefficient was chosen in accordance with the event water input (EWI), 0.1 for EWI less than $90 \mathrm{~mm}, 0.15$ for EWI between 90 and $250 \mathrm{~mm}$, and 0.2 for EWI greater than $250 \mathrm{~mm}$ (Ministry of Geology and Mineral Resources, 1986). The equation used under these experimental conditions was $\mathrm{ET}=\mathrm{P}+\mathrm{I}+\Delta \mathrm{W}-\mathrm{D}$.

Water use efficiency (WUE). WUE was calculated as WUE $=\mathrm{GY} / \mathrm{ET}$ where $G Y$ is grain yield $\left(\mathrm{kg} \mathrm{m}^{-3}\right)$ and $E T$ was obtained by the abovementioned formula.

Potential ET (ETp). Evapotranspiration without water deficit (ETp or full ET) was calculated by $\mathrm{ET}_{0}$ multiplied by a crop coefficient derived from the Luancheng station of the NCP (Liu et al., 2002); $\mathrm{ET}_{0}$ was calculated by the Penman-Monteith equation recommended by FAO (Allen et al., 1998). The seasonal potential ET (ETp) is shown in Figure 1.

\section{Statistical analysis}

All data collected were statistically analyzed as a

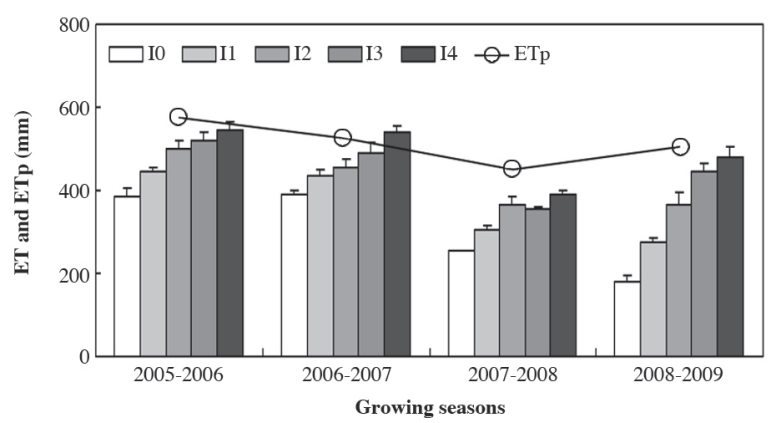

I0: rainfed; I1: one irrigation; I2: two irrigations; I3: three irrigations; I4: four irrigations.

Figure 1. Evapotranspiration (ET) and potential ET (ETp) in different water supply conditions from 2005 to 2009 . completely randomized design with four replicates by ANOVA to test the difference in GY, spike number, grain number per spike, 1000-grain weight, water storage at harvest, soil water depletions (SWD), water supply, ET, root weight, and root-shoot ratio among different treatments. When the F-test indicated statistical significance at $\mathrm{P} \leq 0.05$, mean comparisons were made by LSD.

The ET regression analysis, pre-sowing soil water storage (PSWS) at the $2 \mathrm{~m}$ depth, and water supply (total volume of rainfall and irrigation) was performed with the DPS 11.5 data processing system (Tang, 2009) to analyze the correlation between ET and these variables and the contribution of each dependent variable to ET. Similarly, regression analysis of 1000-grain weight and its dependent variables, such as sunshine duration, wind speed, average temperature, humidity, rainfall, hot and dry wind, and irrigation were also performed with DPS.

\section{RESULTS AND DISCUSSION}

\section{Influence of irrigation on GY, ET, and WUE}

Grain yield. Mean GY, yield components, and WUE values of SM15 and SX733 with different irrigation treatments between 2005 and 2009 are shown in Table 4 . The weather was dry with seasonal precipitation less than $95 \mathrm{~mm}$ during the 2005-2006 and 2008-2009 seasons. However, it was normal in 2006-2007 and slightly wet in 2007-2008 with 120 to $165 \mathrm{~mm}$ seasonal rainfall in both seasons (Table 3). In the 2007-2008 season, delayed sowing and less ET significantly reduced GY (16.8\%) as compared with the other three seasons (Table 4). The most frequently irrigated treatment (I4) in three of the four seasons slightly decreased maximum GY by $0.7 \%$ to $2.3 \%$ instead of the expected increase. Although late sowing resulted in an insufficient plant population in the 2007-2008 season, the last irrigation event at the reviving stage significantly increased spike number (14\%) and produced maximum GY for four irrigation treatments. The three irrigation events greatly improved GY in the 2005-2006 and 2008-2009 dry years, but slightly reduced it in the 2006-2007 normal season $(0.6 \%)$ and in the 2007-2008 wet season (1.2\%). Two irrigation events (I2) 
Table 4. Mean grain yield, yield components, and water use efficiency (WUE) for both wheat cultivars from 2005 to 2009.

\begin{tabular}{|c|c|c|c|c|c|}
\hline Treatments & $\begin{array}{l}\text { Spike } \\
\text { number }\end{array}$ & $\begin{array}{l}\text { Grain number } \\
\text { per spike }\end{array}$ & $\begin{array}{l}\text { 1000-kernel } \\
\text { weight }\end{array}$ & $\begin{array}{l}\text { Grain } \\
\text { yield }\end{array}$ & WUE \\
\hline & $10^{4}$ plant ha $^{-1}$ & & g & $\mathrm{kg} \mathrm{ha}^{-1}$ & $\mathrm{~kg} \mathrm{~m}^{-3}$ \\
\hline \multicolumn{6}{|l|}{$2005-2006$} \\
\hline I0 & $608.6 \mathrm{~b}$ & $29.5 b$ & $39.9 \mathrm{c}$ & $6986 c$ & $1.82 \mathrm{~b}$ \\
\hline I1 & $771.4 \mathrm{a}$ & $29.1 b$ & $38.3 \mathrm{c}$ & $8619 b$ & $1.94 \mathrm{a}$ \\
\hline $\mathrm{I} 2$ & $766.5 \mathrm{a}$ & $30.2 b$ & $41.1 \mathrm{a}$ & $8960 a b$ & $1.79 \mathrm{bc}$ \\
\hline I3 & $783.6 \mathrm{a}$ & $31.0 \mathrm{ab}$ & $40.7 \mathrm{~b}$ & $9322 \mathrm{a}$ & $1.79 b c$ \\
\hline I4 & $808.5 \mathrm{a}$ & $32.5 \mathrm{a}$ & $37.6 \mathrm{c}$ & $9261 \mathrm{ab}$ & $1.70 \mathrm{c}$ \\
\hline \multicolumn{6}{|l|}{ 2006-2007 } \\
\hline I0 & $699.0 \mathrm{a}$ & $30.4 \mathrm{a}$ & $39.2 \mathrm{ab}$ & $8720 b$ & $2.24 \mathrm{a}$ \\
\hline I1 & $728.6 a$ & $31.3 \mathrm{a}$ & $38.3 b$ & $9533 a b$ & $2.18 \mathrm{a}$ \\
\hline $\mathrm{I} 2$ & $743.8 \mathrm{a}$ & $30.6 \mathrm{a}$ & $40.4 \mathrm{a}$ & $9732 \mathrm{a}$ & $2.14 \mathrm{a}$ \\
\hline I3 & 742.9a & $31.5 \mathrm{a}$ & $40.5 \mathrm{a}$ & $9672 \mathrm{a}$ & $1.98 \mathrm{~b}$ \\
\hline I4 & $741.0 \mathrm{a}$ & $30.7 \mathrm{a}$ & $38.1 \mathrm{~b}$ & $9511 \mathrm{a}$ & $1.76 \mathrm{c}$ \\
\hline \multicolumn{6}{|l|}{ 2007-2008 } \\
\hline I0 & $584.0 \mathrm{c}$ & $29.3 \mathrm{ab}$ & $41.7 \mathrm{~b}$ & $6884 d$ & $2.71 \mathrm{a}$ \\
\hline I1 & $643.3 b$ & $29.2 b$ & $39.8 \mathrm{c}$ & $7530 \mathrm{c}$ & $2.48 b$ \\
\hline $\mathrm{I} 2$ & $635.6 \mathrm{~b}$ & $29.8 \mathrm{ab}$ & $42.9 \mathrm{ab}$ & $7700 \mathrm{bc}$ & $2.11 \mathrm{c}$ \\
\hline I3 & $633.0 \mathrm{~b}$ & $30.2 \mathrm{a}$ & $43.0 \mathrm{a}$ & $7970 \mathrm{ab}$ & $2.24 \mathrm{~cd}$ \\
\hline I4 & $702.3 \mathrm{a}$ & $30.0 \mathrm{ab}$ & $39.7 \mathrm{c}$ & $8063 a$ & $2.07 \mathrm{~d}$ \\
\hline \multicolumn{6}{|l|}{ 2008-2009 } \\
\hline I0 & $647.3 \mathrm{c}$ & $26.5 \mathrm{c}$ & $42.1 \mathrm{a}$ & $7559 \mathrm{c}$ & $4.20 \mathrm{a}$ \\
\hline I1 & $765.0 \mathrm{abc}$ & $29.7 \mathrm{ab}$ & $39.1 \mathrm{~b}$ & $9710 \mathrm{~b}$ & $3.52 b$ \\
\hline $\mathrm{I} 2$ & $755.5 b c$ & $30.1 \mathrm{a}$ & $43.0 \mathrm{a}$ & $9801 b$ & $2.67 \mathrm{c}$ \\
\hline I3 & $776.8 \mathrm{ab}$ & $30.9 \mathrm{a}$ & $42.4 \mathrm{a}$ & $10158 \mathrm{a}$ & $2.28 \mathrm{~d}$ \\
\hline I4 & $845.3 \mathrm{a}$ & $29.4 b$ & $40.6 a b$ & $10037 \mathrm{a}$ & $2.09 \mathrm{~d}$ \\
\hline
\end{tabular}

Different letters in a row indicate significant differences according to LSD test $(\mathrm{P} \leq 0.05)$.

I0: Rainfed; I1: one irrigation event; I2: two irrigation events; I3: three irrigation events; I4: four irrigation events.

Table 5. Mean soil water depletion (SWD), water supply, and evapotranspiration (ET) for both wheat cultivars with different water supply conditions from 2005 to 2009.

\begin{tabular}{|c|c|c|c|c|c|c|}
\hline Treatments & PSWS & $\begin{array}{l}\text { Water storage } \\
\text { at harvest }\end{array}$ & SWD & $\begin{array}{l}\text { Water } \\
\text { supply }\end{array}$ & ET & $\begin{array}{c}\text { Percentage } \\
\text { of } \\
\text { SWD }\end{array}$ \\
\hline & & $\mathrm{mm}$ & & 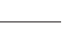 & & $\%$ \\
\hline \multicolumn{7}{|l|}{$2005-2006$} \\
\hline I0 & 610 & $369 \mathrm{c}$ & $241 \mathrm{a}$ & $142 \mathrm{e}$ & $383 d$ & $63 a$ \\
\hline I1 & 610 & $379 \mathrm{c}$ & $232 \mathrm{a}$ & $213 d$ & $445 c$ & $52 \mathrm{~b}$ \\
\hline $\mathrm{I} 2$ & 610 & $381 \mathrm{c}$ & $229 a$ & $270 \mathrm{c}$ & $499 b$ & $46 c$ \\
\hline I3 & 610 & $421 b$ & $190 \mathrm{~b}$ & $332 b$ & $522 \mathrm{~b}$ & $36 \mathrm{~d}$ \\
\hline I4 & 610 & $455 \mathrm{a}$ & $156 \mathrm{c}$ & $390 \mathrm{a}$ & $546 a$ & $29 \mathrm{e}$ \\
\hline \multicolumn{7}{|l|}{$2006-2007$} \\
\hline I0 & 587 & $323 c$ & $264 a$ & $125 \mathrm{e}$ & $389 d$ & $68 \mathrm{a}$ \\
\hline I1 & 587 & $341 \mathrm{c}$ & $246 a$ & $192 d$ & $437 \mathrm{c}$ & $56 b$ \\
\hline $\mathrm{I} 2$ & 587 & $387 b$ & $200 b$ & $256 \mathrm{c}$ & $456 c$ & $44 c$ \\
\hline I3 & 587 & $407 \mathrm{ab}$ & $180 \mathrm{bc}$ & $308 b$ & $488 \mathrm{~b}$ & $37 d$ \\
\hline I4 & 587 & $427 \mathrm{a}$ & $160 \mathrm{c}$ & $380 \mathrm{a}$ & $539 a$ & $30 \mathrm{e}$ \\
\hline \multicolumn{7}{|l|}{$2007-2008$} \\
\hline I0 & 472 & $381 d$ & $91 \mathrm{a}$ & $163 \mathrm{e}$ & $254 d$ & $36 a$ \\
\hline I1 & 472 & $388 \mathrm{~d}$ & $84 a$ & $219 d$ & $303 c$ & $28 b$ \\
\hline I2 & 472 & $467 \mathrm{c}$ & $5 b$ & $359 \mathrm{c}$ & $365 b$ & $1 \mathrm{c}$ \\
\hline I3 & 472 & $524 \mathrm{~b}$ & $-52 c$ & $407 \mathrm{~b}$ & $355 b$ & $-15 d$ \\
\hline I4 & 472 & $554 \mathrm{a}$ & $-82 d$ & $472 a$ & $390 \mathrm{a}$ & $-21 \mathrm{e}$ \\
\hline \multicolumn{7}{|l|}{$2008-2009$} \\
\hline I0 & 512 & $425 c$ & $87 \mathrm{a}$ & $93 \mathrm{e}$ & $180 \mathrm{~d}$ & $48 \mathrm{a}$ \\
\hline I1 & 512 & $428 \mathrm{c}$ & $84 a$ & $192 d$ & $276 \mathrm{c}$ & $30 b$ \\
\hline $\mathrm{I} 2$ & 512 & $450 \mathrm{bc}$ & $62 \mathrm{ab}$ & $305 c$ & $367 b$ & $17 \mathrm{c}$ \\
\hline I3 & 512 & $474 a b$ & $38 \mathrm{bc}$ & $407 b$ & $445 \mathrm{a}$ & $9 d$ \\
\hline I4 & 512 & $498 \mathrm{a}$ & $14 \mathrm{c}$ & $466 a$ & $480 \mathrm{a}$ & $3 d$ \\
\hline
\end{tabular}

PSWS: Pre-sowing soil water storage; I0: rainfed; I1: one irrigation event; I2: two irrigation events; I3: three irrigation events; I4: four irrigation events.

Values followed by the same letter in the same season and column, were not significant at $\mathrm{P}<0.05$. produced the highest GY in the 2006-2007 normal season, but significantly decreased it in the 2008-2009 and 20052006 dry years. A reduction of $6.5 \%$ in GY only occurred in the 2005-2006 dry season and it was $2 \%$ in the 20062007 normal season. Approximately $75 \%$ to $90 \%$ of the maximum yield was obtained under rainfed conditions in the dry and normal seasons with abundant PSWS in the 0 to $200 \mathrm{~cm}$ soil profile. Grain yield for I2 was not higher $(\mathrm{P} \leq 0.05)$ in the 2008-2009 dry season than for I1. This was possibly due to rainfall of $23.8 \mathrm{~mm}$ on 10 May, which was just after wheat anthesis and counteracted the effect of the second irrigation event during this stage. Some studies report that more frequent irrigation enhances yield (Wallach et al., 2003), but others find no difference (Xu et al., 2004). Recently, many research studies have shown that more water supply optimization resulted in decreased GY and WUE (Zhang et al., 2003), which agrees with the reports of our research. These contradictory results may be a consequence of differences in cultivation, soils, irrigation methods, and climate.

Yield components. Drought caused by lack of rainfall resulted in a $13.1 \%$ plant population reduction for I0 as compared with other treatments (Table 4). The grain number per spike tended to decrease during the dry period caused by low rainfall, but the significant decline was only observed in 2008-2009 (dry year). One irrigation treatment around the early jointing stage (31) can ensure proper spike number and grain number per spike as evidenced by similar values among I1, I2, and I3. An additional early irrigation event at the reviving stage (28-29) for I4 usually further increased spike number with no influence on grain number. Compared with other treatments, higher kernel weight was $5.6 \%$ higher when either I 2 or I 3 was conducted. This suggests that a supplemental irrigation event at the milk grain stage (75) for I4 was not very effective to promote grain weight. In contrast, I2 or I3 and I1 and I4 led to the lowest kernel weight because of the too dry or excessively moist soil conditions. As compared with I1 and I4, grain weight increased by $5.0 \%$ when there was no irrigation at all. This was mainly obtained by the self-adjustment mechanism among the three yield components and higher mobilization efficiency to the grain (Zhang et al., 2008).

WUE. Our results showed that WUE decreased with increasing water supply in three of the four years. Given the severe water shortage situation in the NCP, a balance between yield and WUE would be useful to evaluate the irrigation system. When irrigation increases, WUE decreases (Zhang et al., 2008; 2010). However, it is possible to achieve both objectives simultaneously, that is, satisfactory WUE and yield, by regulating irrigation times. In the 2005-2006 season, I3 had the highest GY but a lower WUE as compared with I2. In 2006-2007, I2 produced the highest GY, but only decreased WUE by 
$1.8 \%$ as compared with I1. In 2007-2008, I4 achieved the highest GY, while its WUE was $1.9 \%$ lower as compared with I2. Therefore, I3, I2, and I4 were recommended because they achieved maximum yield and satisfactory WUE in those three seasons. In 2008-2009, I1 should be suggested because there was a $4.4 \%$ yield reduction and a $54.3 \%$ increase in WUE as compared with the highest yield treatment (I3). In the 2008-2009 dry season, mean WUE was as high as $3.0 \mathrm{~kg} \mathrm{~m}^{-3}$ with a $41.2 \%$ increase as compared with the mean of the other three seasons due to a $10.3 \%$ yield increase and $16.8 \%$ ET reduction (Table 5). Especially compared with the 2006-2007 season, mean water supply in the 2008-2009 season increased by $16 \%$, but mean ET decreased by $24 \%$. Lower ET in this season was primarily attributed to a $71.9 \%$ reduction of SWD as compared with the 2005-2006 and 2006-2007 seasons. In the 2007-2008 wet season, a $17.1 \%$ reduction in PSWS also significantly reduced ET by $16.8 \%$ as compared with the other three seasons; therefore, its WUE was higher than in the 2005-2006 and 2006-2007 seasons. Results indicate that PSWS has a great impact on WUE.

The most frequently irrigated treatment (I4) in three of the four seasons slightly decreased maximum GY; maximum GY can be achieved with three irrigation treatments (irrigation at jointing, flowering, and milk stages) in the dry seasons and two irrigation treatments (irrigation at jointing and flowering stages) in normal seasons, which agrees with Zhang et al. (2003) and Sun et al. (2010). In three of the four years (2006-2008), the highest yield was achieved with an acceptable WUE decrease $(<2 \%)$. In 2008-2009, an acceptable yield loss $(<5 \%)$ was used to obtain a significant operating profit water use index (up to $50 \%$ ).

ET. ETp, ET, and its components in different growing seasons are shown in Figure 1 and Table 5. ET and ETp followed the same trend. Winter wheat ET ranged from 180 to $546 \mathrm{~mm}$ in the different precipitation seasons and irrigation treatments. It increased gradually when the water supply increased and the highest value occurred when four irrigation events were conducted each year. Evapotranspiration of I4 was close to ETp, especially in the 2006-2007 season and was just $14 \mathrm{~mm}$ higher than ETp. Analysis of the results showed that the total volume of water used during the maximum production year was below ETp in the four seasons. Maximum yield can be achieved with an ET from $8 \%$ to $27 \%$ less than ETp. These results indicate that four irrigation events are excessive and it is necessary to reduce irrigation.

The relationships between water supply:ET and GY of winter wheat in the different rainfall years are shown in Figure 2. The simulation result of the quadratic curve model showed that the highest yields can be achieved when water consumption from 2005 to 2009 was 532, 487,414 , and $408 \mathrm{~mm}$, respectively, with an average of $460 \mathrm{~mm}$.
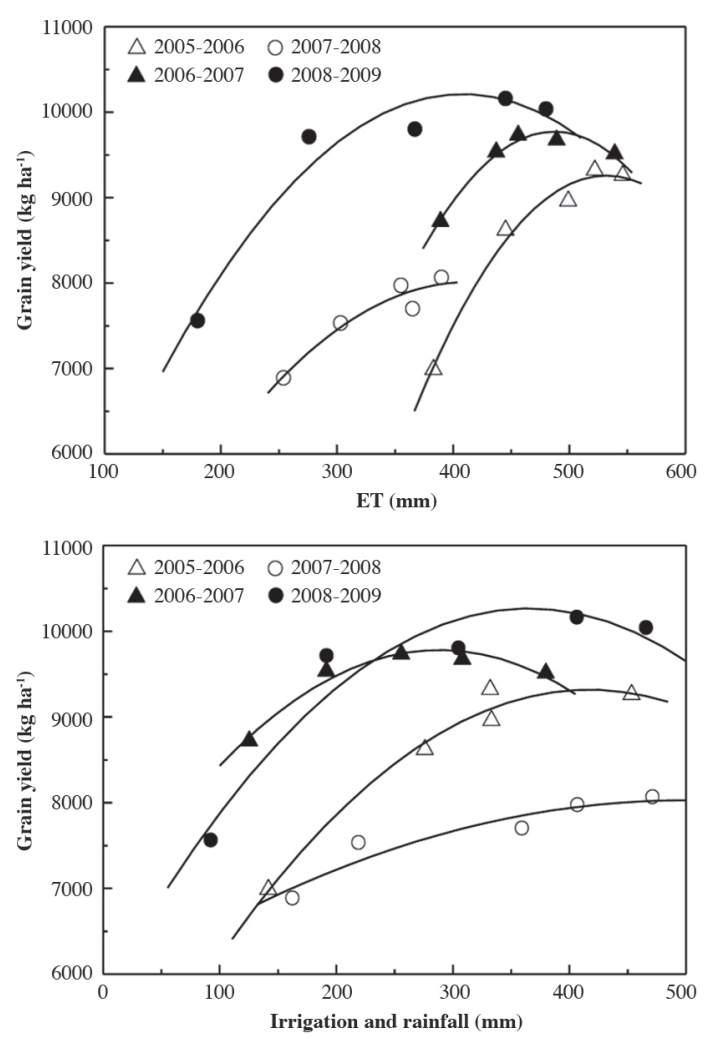

Figure 2. Relationship between grain yield and seasonal evapotranspiration (ET) or water supply in different water supply conditions from 2005 to 2009.

The average amount of water to obtain maximum GY was estimated as $357 \mathrm{~mm}$ ( 289 to $417 \mathrm{~mm}$ ) in the three 2005-2006, 2006-2007, and 2008-2009 seasons, which was $66.6 \%$ of ETp (55.0\% to $72.5 \%)$. With an average seasonal rainfall of $143 \mathrm{~mm}$ in the NCP, supplemental irrigation water was approximately $214 \mathrm{~mm}$ in a normal year in order to obtain maximum yield.

Evapotranspiration of irrigated winter wheat in the $\mathrm{NCP}$ was influenced by many factors, including water supply, irrigation time, PSWS, and ETp. Stepwise multiple regression statistical analysis showed that water supply amount and PSWS were the main impact factors. The following regression equation displayed the relationship among ET (Y), PSWS (X1), and water supply amount (X2) for the 2005 to 2009 period: $\mathrm{Y}=-548.9+1.425 \mathrm{X} 1$ $+0.624 \mathrm{X} 2,\left(\mathrm{R}=0.969^{* *}, \mathrm{n}=19\right)$. The partial correlation coefficients of the two variables were similar and higher PSWS and water supply led to higher ET (Table 6). The same order existed between the direct path coefficient and the partial correlation coefficient (Table 7); the direct path coefficient was P1y $(0.821)>$ P2y $(0.725)$. This result indicates that PSWS played a decisive role in ET composition, while the direct effect of water supply on ET was less important when compared to PSWS.

Since soil water storage was different during the growing seasons, SWD showed PSWS depletion (Table 5), which was mainly controlled by PSWS and later rainfall. 
Table 6. Partial correlation of evapotranspiration (Y) with pre-sowing soil water storage (X1) and water supply amount (X2).

\begin{tabular}{lccc}
\hline $\begin{array}{l}\text { Partial correlation } \\
\text { coefficient }\end{array}$ & $\begin{array}{c}\text { Partial correlation } \\
\text { coefficient value }\end{array}$ & t value & $\begin{array}{c}\text { Significant } \\
\text { level (P) }\end{array}$ \\
\hline $\mathrm{r}(\mathrm{y}, \mathrm{X} 1)=$ & 0.955 & 13.335 & 0.000 \\
$\mathrm{r}(\mathrm{y}, \mathrm{X} 2)=$ & 0.944 & 11.768 & 0.000 \\
\hline
\end{tabular}

Table 7. Contribution to evapotranspiration of dependent variables.

\begin{tabular}{lccc}
\hline & \multicolumn{3}{c}{ Path coefficient } \\
\cline { 2 - 4 } Variable & Direct coefficient & $\rightarrow \mathrm{X} 1$ & $\rightarrow \mathrm{X} 2$ \\
\hline $\mathrm{X} 1$ & 0.821 & & -0.159 \\
$\mathrm{X} 2$ & 0.725 & -0.180 & \\
\hline
\end{tabular}

Coefficient of determination $=0.937$.

It contributed greatly to grain production when PSWS was higher in the 2005-2006 and 2006-2007 seasons. Due to the deep soil profile within the root zone (about $2 \mathrm{~m}$ ), stored soil moisture extracted by the winter wheat root system was $66 \%$ of ET for I0. Even for I1, I2, I3, and I4, SWD was still 54\%, 45\%, 37\%, and 29\% of total seasonal ET (Table 5). Therefore, the irrigation treatment must take into account stored soil moisture in the root zone profile. In the 2007-2008 and 2008-2009 seasons, lower PSWS and more rainfall in early June resulted in lower SWD. The stored soil moisture extracted by the winter wheat root system was $42 \%, 29 \%, 9 \%,-3 \%$, and $-9 \%$ of ET of I0, I1 , I2, I3, and I4, respectively, in these two seasons.

Soil water depletion, precipitation, and irrigation contributed to $45 \%, 23 \%$, and $32 \%$, respectively, of the total seasonal ET for maximum yield production when PSWS was higher. They were $8 \%, 47 \%$, and $45 \%$, respectively, when PSWS decreased. It is generally believed that maximum PSWS in the NCP should be obtained by pre-planting irrigation when rainfall is insufficient in the summer rainy season. However, the present study reveals that an appropriate PSWS, rather than the maximum, should be established for better GY and WUE.

Different responses of the two cultivars to irrigation regimes related to grain yield and its components

The two cultivars responded differently to irrigation treatments throughout the four years (Figure 3). In dry years, the water-saving cv. SM15 demonstrated remarkable superiority over the higher yielding cv. SX733, with increases of $6.1 \%$ and $16.6 \%$ in mean and maximum

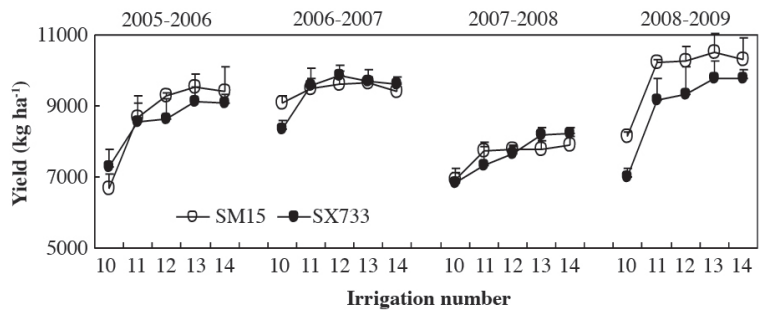

Figure 3. Grain yield, spike number, grain number per spike, and 1000-grain weight of wheat 'Shimai15' (SM15) and 'Shixin733' (SX733) under different water supply conditions from 2005 to 2009. yields, respectively. In the normal year (2006-2007) and in wet year (2007-2008), yields of cv. SM15 tended to be higher than cv. SX733 when less irrigation was applied. This tendency was reverted when more irrigation was applied. In the four years, both cultivars achieved maximum yields under three irrigation treatments. Yields of SM15 usually varied less than SX733 among different irrigation applications and achieved $82.4 \%$, $96.5 \%$, and $98.6 \%$ of the maximum with the I0, I1, and I2 irrigation treatments, respectively, as compared with $80.1 \%, 94.2 \%$, and $96.3 \%$ for SX733. This suggests that yield of the water-saving cv. SM15 is more stable in a dry environment.

Total ET was very similar in the two wheat cultivars (Table 8). Root distribution in the soil profile is an important factor in plant water and nutrient availability. Some studies found that the soil water depletion front was closely related to rooting depth (Angadi and Entz, 2002), and the scarcity of roots in deep soil layers often restricted the full utilization of available soil water (Barraclough and Weir, 1988; Zhang et al., 2004). However, other studies highlighted the primary role of the top root system in soil water uptake (Clothier and Green, 1994) and considered that the roots in the top soil were more important for water uptake when soil moisture was not restricted. For SM15, whose total root weight was $48 \%$ higher than SX733, approximately $82 \%$ and $18 \%$ of roots were distributed in 0 to $70 \mathrm{~cm}$ and 70 to $140 \mathrm{~cm}$ soil layers, respectively (Table 9). Roots of SX733 were much deeper than SM15 roots and approximately $80 \%, 15 \%$, and $5 \%$ of roots were distributed in 0 to 70,70 to 140 , and 140 to $200 \mathrm{~cm}$ soil

Table 8. Change in soil water content, irrigation, precipitation, and evapotranspiration (ET) of wheat 'Shimai15' (SM15) and 'Shixin733' (SX733) in different water supply conditions in 2007-2008 season (mm).

\begin{tabular}{llccccc}
\hline \multirow{2}{*}{$2007-2008$} & & PSWS & $\begin{array}{c}\text { Water storage } \\
\text { at harvest }\end{array}$ & SWD & $\begin{array}{c}\text { Water } \\
\text { supply }\end{array}$ & ET \\
\hline SM15 & I0 & 472 & $388 \mathrm{c}$ & $84 \mathrm{a}$ & $163 \mathrm{e}$ & $247 \mathrm{~d}$ \\
& I1 & 472 & $384 \mathrm{c}$ & $89 \mathrm{a}$ & $219 \mathrm{~d}$ & $308 \mathrm{c}$ \\
& I2 & 472 & $464 \mathrm{~b}$ & $8 \mathrm{~b}$ & $359 \mathrm{c}$ & $368 \mathrm{~b}$ \\
& I3 & 472 & $531 \mathrm{a}$ & $-58 \mathrm{c}$ & $407 \mathrm{~b}$ & $349 \mathrm{~b}$ \\
& I4 & 472 & $546 \mathrm{a}$ & $-74 \mathrm{c}$ & $472 \mathrm{a}$ & $398 \mathrm{a}$ \\
SX733 & I0 & 472 & $373 \mathrm{~d}$ & $99 \mathrm{a}$ & $163 \mathrm{e}$ & $261 \mathrm{c}$ \\
& I1 & 472 & $393 \mathrm{~d}$ & $79 \mathrm{a}$ & $219 \mathrm{~d}$ & $298 \mathrm{~b}$ \\
& I2 & 472 & $471 \mathrm{c}$ & $2 \mathrm{~b}$ & $359 \mathrm{c}$ & $361 \mathrm{a}$ \\
& I3 & 472 & $517 \mathrm{~b}$ & $-45 \mathrm{c}$ & $407 \mathrm{~b}$ & $362 \mathrm{a}$ \\
& I4 & 472 & $562 \mathrm{a}$ & $-89 \mathrm{~d}$ & $472 \mathrm{a}$ & $382 \mathrm{a}$ \\
\hline
\end{tabular}

PSWS: Pre-sowing soil water storage; SWD: soil water depletion.

Values followed by the same letter in the same season and column were not significant at $\mathrm{P}<0.05$.

Table 9. Root weight and root-shoot ratio of wheat 'Shimai15' (SM15) and 'Shixin733' (SX733).

\begin{tabular}{|c|c|c|c|c|c|}
\hline \multirow[b]{2}{*}{ Treatments } & \multicolumn{3}{|c|}{ Root weight } & \multirow[b]{2}{*}{$\begin{array}{c}\text { Total root } \\
\text { weight }\end{array}$} & \multirow[b]{2}{*}{$\begin{array}{l}\text { Root-shoot } \\
\text { ratio }\end{array}$} \\
\hline & $0-70 \mathrm{~cm}$ & $70-140 \mathrm{~cm}$ & $>140 \mathrm{~cm}$ & & \\
\hline & & - g plant & & & $\%$ \\
\hline SX733 & $0.917 \mathrm{~B}$ & $0.174 \mathrm{~B}$ & $0.056 \mathrm{~A}$ & 1.147B & $7.3 \mathrm{~B}$ \\
\hline SM15 & $1.390 \mathrm{~A}$ & $0.304 \mathrm{~A}$ & $0.000 \mathrm{~B}$ & $1.694 \mathrm{~A}$ & $10.5 \mathrm{~A}$ \\
\hline
\end{tabular}

Values followed by the same letter in the same season and column were not significant at $\mathrm{P}<0.05$. 
layers, respectively. The analysis of the results indicates that the higher total root weight and root-shoot ratio is important for the water-saving cv. SM15 and massive soil profile water was absorbed by the roots in the top soil layers; the water-saving cv. SM15 demonstrated remarkable GY over the higher yielding cv. SX733, especially in dry years. Its larger root system contributed to yield stability by absorbing more water from deep soil, while most soil profile water was absorbed by deeper roots in the higher yielding SX733 cultivar. Thus, due to the frequent extreme climate in the NCP, especially dry weather, high-yielding and strongly drought-resistant wheat should first be considered.

\section{Relationship between yield components and meteorological factors}

The variation of yield components mainly depends on cultivation practices, varieties, and meteorological factors, such as seasonal precipitation distribution, active accumulated temperature $\left(\Sigma \mathrm{t} \geq 0{ }^{\circ} \mathrm{C}\right)$, average temperature, sunshine duration, hot and dry wind, and air humidity. The spike number was greatly stimulated by the higher $\sum \mathrm{t}\left(\geq 0{ }^{\circ} \mathrm{C}\right)$ during the sowing and dormant periods. Before the winter wheat reviving stage (28), suitable climatic conditions can promote effective spikelet number, which is the foundation of high yield. Moreover, a larger population will be formed if the accumulated temperatures are high enough before winter (Xing et al., 2005). The results in the present study showed that there was a significantly positive correlation between spike number and $\sum \mathrm{t}$ from sowing to the dormant period from 2005 to $2009\left(\mathrm{r}=0.585^{* *}, \mathrm{n}=19\right)$ (Figure 4); an appropriately high temperature in the winter improves wheat production, which agrees with $\mathrm{Li}$ et al. (2009).

Some studies found that the growth rate and many crop plant development processes are controlled by temperature. Lobell and Field (2007) reported a $0.6 \%$ to $8.9 \%$ reduction in mean crop (wheat, maize, rice) yield for each $1{ }^{\circ} \mathrm{C}$ increase in temperature on the global scale. Spike differentiation is one of the most essential stages for wheat reproductive development and the foundation of spike characters. Some environmental factors affect spike differentiation processes and result in yield

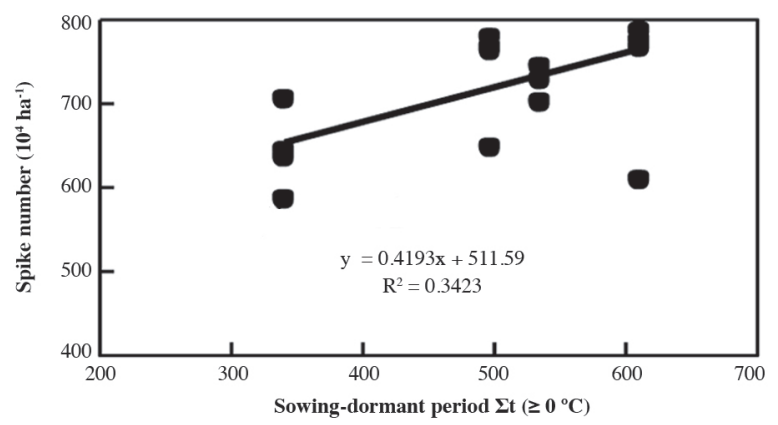

Figure 4. Relationship between spike number and $\Sigma \mathrm{t}\left(\geq 0^{\circ} \mathrm{C}\right)$ in sowing to dormant period from 2005 to 2009. variability. Results showed that grain number per spike was negatively correlated with average temperature in March and April $\left(\mathrm{r}=-0.514^{*}, \mathrm{n}=19\right)$ during the spike differentiation period (Figure 5). The lower average temperature (approximately $11.7^{\circ} \mathrm{C}$ ) in March and April tended to delay spike differentiation and significantly promoted grain number per spike.

Meteorological changes from the milk to harvest stage are important factors influencing grain weight. The relationship between 1000-grain weight and meteorological factors is shown in Figure 6. There were significant correlations between grain weight and average temperature, sunshine duration, and wind speed. Since the variation of grain weight is caused by the interaction of many factors, including meteorological changes and irrigation, a stepwise regression equation is used here to show their relationships from 2005 to 2009 : $\mathrm{Y}=30.232+$ $1.079 \mathrm{X} 2-0.549 \mathrm{X} 4$ where $\mathrm{Y}$ is 1000 -grain weight, $\mathrm{X} 2$ and $\mathrm{X} 4$ are sunshine duration and wind speed, respectively. Furthermore, other dependent variables of $\mathrm{X}$ include average temperature (X1), humidity (X3), rainfall (X5), dry and hot wind days (X6), and irrigation (X7). Results showed that sunshine duration and wind speed were the most important factors influencing grain weight; there was a significant correlation between these two variables and grain weight $\left(\mathrm{R}=0.999^{*}, \mathrm{n}=3\right)$. The partial correlation coefficients of the two variables were similar (Table 10). Results showed that longer daylight hours and an appropriate wind speed $\left(1.5-2 \mathrm{~m} \mathrm{~s}^{-1}\right)$ were beneficial to improve grain weight. The direct path coefficient and the partial correlation coefficient were in the same order (Table 11), and the direct pass coefficient was P2y (1.160) $>$ P4y (0.200). Results exhibited that sunshine duration played a key role in the formation of grain weight, while the direct influence of wind speed on grain weight was less important. The highest 1000-kernel weight was achieved in the 2007-2008 and 2008-2009 seasons with $5.1 \%$ increase as compared with other seasonal gains. In this research study, the effect of rainfall at the milk stage was not apparent. However, some studies (Li et al., 2009) found that the highest correlation time between GY and periodical precipitation was in the milk stage; moreover, a high level of soil moisture during the milk grain stage

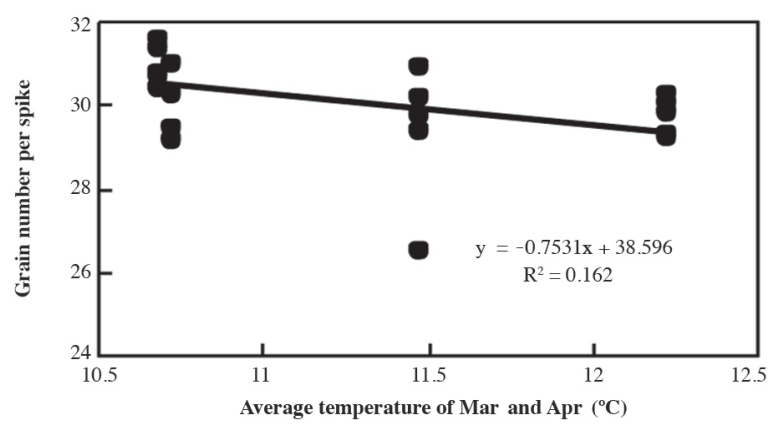

Figure 5. Relationship between grain number per spike and average temperature in March and April from 2005 to 2009. 

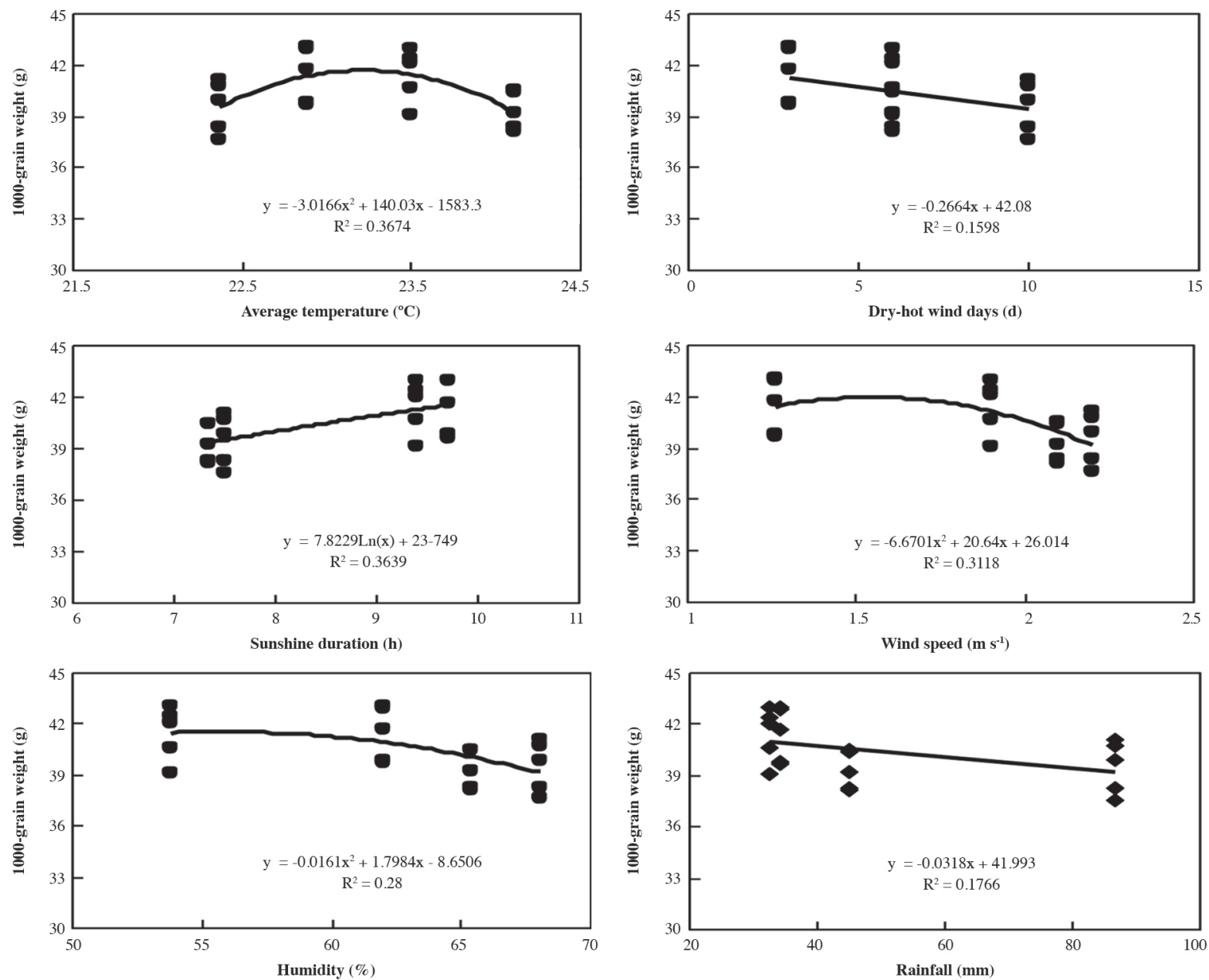

Figure 6. Relationship between 1000-grain weight and meteorological factors for the last $20 \mathrm{~d}$ before harvest for 2005 to 2009.

is not beneficial and can lead to reduced grain weight and GY (Jia et al., 2009).

CONCLUSIONS

High temperatures reduce wheat yield in the NPC. An The most frequently irrigated treatment (I4) in three of the extreme climate frequently occurs, such as extreme high four seasons slightly decreased maximum GY, which can temperatures at the late milk stage and chilling damage be achieved with three irrigation treatments (irrigation at the pre-winter or reviving stage. This should therefore at jointing, flowering, and milk stages) in dry seasons be considered when deciding the sowing date, variety and two irrigation treatments (irrigation at jointing selection, and all other agronomic practices.

Table 10. Partial correlation of the 1000-grain weight $(Y)$ with sunshine duration (X2) and wind speed (X4) from the late milk stage to harvest stage.

\begin{tabular}{lccc}
\hline $\begin{array}{l}\text { Partial correlation } \\
\text { coefficient }\end{array}$ & $\begin{array}{c}\text { Partial correlation } \\
\text { coefficient value }\end{array}$ & $\mathrm{t}$ value & $\begin{array}{c}\text { Significant } \\
\text { level }(\mathrm{P})\end{array}$ \\
\hline $\mathrm{r}(\mathrm{y}, \mathrm{X} 2)$ & 1.000 & 45.243 & 0.000 \\
$\mathrm{r}(\mathrm{y}, \mathrm{X} 4)$ & 0.992 & 7.787 & 0.016 \\
\hline
\end{tabular}

Table 11. Contribution to grain weight of dependent variables.

\begin{tabular}{lccc}
\hline & \multicolumn{3}{c}{ Path coefficient } \\
\cline { 2 - 4 } Variable & Direct coefficient & $\rightarrow \mathrm{X} 2$ & $\rightarrow \mathrm{X} 4$ \\
\hline $\mathrm{X} 2$ & 1.160 & & -0.166 \\
$\mathrm{X} 4$ & 0.200 & -0.967 & \\
\hline
\end{tabular}
and flowering stages) in normal seasons. An additional irrigation at the reviving stage can significantly promote yield by increasing spike number in those years with insufficient wheat population at the pre-winter stage due to late sowing or insufficient accumulated temperature.

Grain yield was significantly related to seasonal full ET and a 410 to $530 \mathrm{~mm}$ seasonal full ET, including 143 $\mathrm{mm}$ rainfall and $214 \mathrm{~mm}$ irrigation water, which led to maximum GY.The present study shows that an appropriate PSWS, rather than the maximum, should be established for better GY and WUE. With the integrated contribution of optimal irrigation manipulation, appropriate PSWS, favorable weather conditions, WUE was as high as 3.52 $\mathrm{kg} \mathrm{m}^{-3}$ with yield up to $9710 \mathrm{~kg} \mathrm{ha}^{-1}$ in 2008-2009. 
In dry years, the water-saving SM15 cultivar demonstrated remarkable GY over the higher yielding SX733 cultivar, while both cultivars achieved very similar GYs in the normal and wet years. For SM15, its larger root system contributed to yield stability by absorbing more water from deep soil. Thus, due to the frequent extreme climate in the NCP, especially dry weather, highyielding and strongly drought-resistant wheat should first be considered.

\section{ACKNOWLEDGEMENTS}

This research was funded by the Public Industry Research Project of the Ministry of Agriculture (nr 201203100), the National Scientific and Technological Supporting Scheme (nr 2011BAD29B01), China, and Crop physiology and ecology and cultivation Key Laboratory of the Ministry of Agriculture ( $\mathrm{nr}$ 201304). The authors are very grateful to Jiexuan Cao for statistic analysis in research data.

\section{LITERATURE CITED}

Al-Kaisi, M.M., A. Berrada, and M. Stack. 1997. Evaluation of irrigation scheduling program and spring wheat yield response in southwestern Colorado. Agricultural Water Management 34:137148.

Allen, R.G., L.S. Pereira, D. Raes, and M. Smith. 1998. Crop evapotranspiration. Guidelines for computing crop water requirements. FAO Irrigation and Drainage Paper nr 56. 300 p. FAO, Rome, Italy.

Angadi, S.V., and M. Entz. 2002. Root system and water use patterns of different height sunflower cultivars. Agronomy Journal 94:136145 .

Angus, J.F., and A.F. Van Herwaarden. 2001. Increasing water use and water use efficiency in dryland wheat. Agronomy Journal 93:290-298.

Barraclough, P.B., and A.H. Weir. 1988. Effects of a compacted subsoil layer on root and shoot growth, water use and nutrient uptake of winter wheat. Journal of Agricultural Science 110:207216.

Clothier, B., and S. Green. 1994. Root zone processes and the efficient use of irrigation water. Agricultural Water Management 25:1-12.

Chmielewski, F.M., and W. Kohn. 2000. Impact of weather on yield components of winter rye over 30 years. Agricultural and Forest Meteorology 102:253-261.

Fereres, E., and M.A. Soriano. 2007. Deficit irrigation for reducing agricultural water use. Journal of Experimental Botany 58:147159.

Ghahraman, B., and A.R. Sepaskhah. 1997. Use of a water deficit sensitivity index for partial irrigation scheduling of wheat and barley. Irrigation Science 18:11-16.

Guo, J.K., S.C. Zhang, M.Q. He, Z.L. Shi, Y.J. Liu, R.Y. Di, et al. 2010. Research of technology of high yield and water-saving and variety-selecting in winter wheat. Acta Agriculturae BorealiSinica 25(suppl.):98-102.

Jia, J.S., and C.M. Liu. 2002. Groundwater dynamic drift and response to different exploitation in the North China Plain: a case study of Luancheng County Hebei Province. Acta Geographica Sinica 57:201-209 (in Chinese).

Jia, X.L., R.K. Ma, Q.G. Zhang, Y.R. Yao, and L.H. Zhang. 2009. Trend in relationship between water supply amount and grain yield of winter wheat from 1987 to 2007. Acta Agriculturae Boreali-Sinica z1 (suppl.):214-217 (In Chinese).
Landau, S., R.A.C. Mitchell, V. Barnett, J.J. Colls, J. Craigon, and R.W. Payne. 2000. A parsimonious, multiple-regression model of wheat yield response to environment. Agricultural and Forest Meteorology 101:151-166.

Li, Y.Y., B.H. Liu, Q.X. Liu, W.Y. Zhang, S.M. Zhang, L.L. Xie, et al. 2009. Effect of climatic conditions on winter wheat yield in Hebei Low Plain. Journal of Triticeae Crops 29:330-334 (In Chinese).

Liu, C.M., and Z.Y. Wei (eds.) 1989. Agricultural hydrology and water resources in the North China Plain. 236 p. Chinese Scientific Press, Beijing, China (In Chinese).

Liu, C.M., X.Y. Zhang, and Y.Q. Zhang. 2002. Determination of daily evaporation and evapotranspiration of winter wheat and maize by large-scale weighing lysimeter and micro-lysimeter. Agricultural and Forest Meteorology 111:109-120.

Lobell, D.B., and C.B. Field. 2007. Global scale climate-crop yield relationships and the impact of recent warming. Environmental Research Letters 2:1-7.

Ministry of Geology and Mineral Resources. 1986. Report on groundwater resources assessment. Ministry of Geology and Mineral Resources, Beijing, China.

Mitchell, R.A.C., C.L. Gibbard, V.J. Mitchell, and D.W. Lawlor. 1996. Effects of shading in different developmental phases on biomass and grain yield of winter wheat at ambient and elevated $\mathrm{CO}_{2}$. Plant, Cell and Environment 19:615-621.

Passioura, J. 2006. Increasing crop productivity when water is scarce-from breeding to field management. Agricultural Water Management 80:176-196.

Shen, Y., and H. Yu. 1998. Effect of soil moisture on the yield and water use efficiency of winter wheat. Advances Geographic Science 17(Suppl.):85-89 (In Chinese).

Sun, H.Y., Y.J. Shen, Q. Yu, G.N. Flerchinger, Y.Q. Zhang, C.M. Liu, and X.Y. Zhang. 2010. Effect of precipitation change on water balance and WUE of the winter wheat - summer maize rotation in the North China Plain. Agricultural Water Management 97:11391145 .

Tang, S.Y. 2009. DPS data processing system-experimental design, statistical analysis and data mining. 665 p. $2^{\text {nd }}$ ed. Science and Technology Press, Beijing, China.

Wallach, R., A. Silber, and G. Xu. 2003. High irrigation frequency: the effect on plant growth and on uptake of water and nutrients. Acta Horticulturae 627:89-96.

Williams, G.D.V. 1971-1972. Geographical variations in yieldweather relationships over a large wheat growing region. Agricultural Meteorology 9:65-283.

Xiao, G.J., and Y.D. Gen. 1999. Index of supplement irrigation with harvested water for dryland in mountainous area of southern Ningxia. Agricultural Research Arid Areas 17:55-60 (In Chinese).

Xing, S.L., G.L. Zhang, H.L. Li, and H.T. Liu. 2005. Analysis of the winter wheat yield components and causes under the extreme climatic conditions. Transactions of the Chinese Society of Agricultural Engineering 21(Suppl.):212-214.

Xu, G., Y. Levkovitch, S. Soriano, R. Wallach, and A. Silber. 2004. Integrated effect of irrigation frequency and phosphorus level on lettuce: P uptake, root growth and yield. Plant and Soil 263:297309.

Zhang, X.Y., S.Y. Chen, H.Y. Sun, D. Pei, and Y.M. Wang. 2008. Dry matter, harvest index, grain yield and water use efficiency as affected by water supply in winter wheat. Irrigation Science 27:1-10.

Zhang, X.Y., S.Y. Chen, H.Y. Sun, Y.M. Wang, and L.W. Shao. 2010. Water use efficiency and associated traits in winter wheat cultivars in the North China Plain. Agricultural Water Management 97:1117-1125.

Zhang, X.Y., D. Pei, and S.Y. Chen. 2004. Root growth and soil water utilization of winter wheat in the North China Plain. Hydrological Processes 18:2275-2287.

Zhang, X.Y., D. Pei, and C.S. Hu. 2003. Conserving groundwater for irrigation in the North China Plain. Irrigation Science 21:159-166. 